\title{
The perils of parody: joking with stereotypes in a postcolonial context in Cien años de soledad
}

\section{Paul McAleer ${ }^{1}$}

School of Modern Languages, Linguistics and Cultures, University of Hull, UK

This article examines the comic treatment of the characters in Cien años de soledad. It challenges the previous studies of the novel's comedy, which have tended to conclude that its comic formulas are necessarily subversive and carnivalesque. Employing Susan Purdie's theory of comedy and Edward Said's, Homi Bhabha's and Walter Mignolo's postcolonial theorisation of othering, the article analyses the ways in which Gabriel García Márquez's comic depictions function as parodic exaggerations of certain stereotypical representations of the Latin American "other." However, it is also argued that the diffuse nature of parody and of the technique of exaggeration open up these jokes to multiple readings. Moreover, according to Stuart Hall's and Richard Dyer's work on stereotypes, references to the "other" in jokes or in other types of narratives inevitably enter into an intertextual dialogue with established discourses, over which the author or text has little control. In this respect, the article aims to map the possible meanings of these jokes within the context of the novel's global popularity. It investigates the possibility that certain comic representations of the "other" in Cien años de soledad run the risk of confirming certain discourses just as much as they have the potential to subvert them.

Keywords: comedy; characterisation; stereotypes; gender; ethnicity; Otherness; neocolonialism; post-colonialism

The few critics who have analysed the use of comedy in Gabriel García Márquez's Cien años de soledad ([1967] 2000) have tackled it from two general perspectives. ${ }^{1}$ Carmelo Gariano (1978), Clive Griffin (1987), André Jansen (1992) and Paul Dixon (1986) focus principally on the type and techniques of comedy employed by GGM. Most other critics (Penuel 1994; Parrilla; Sotomayor 2002; Paoli 1984; Rodríguez Vergara 1991) explore the carnivalesque characteristics of the novel, emphasising its subversive potential in response to the oppressive dogma of Colombia and Latin America, whether that be religious, patriarchal, literary or neocolonial in form. That the majority interpret the novel's comedy through Bakhtin's work is hardly surprising. Most of their studies were published between the 1980s and 90s, a period in which Bakthin's theory enjoyed its greatest popularity. Moreover, the idea that laughter and comedy are the subversive weapons in the hands of the underdog has also enjoyed a certain cultural currency in Latin American academic circles. ${ }^{2}$

\footnotetext{
${ }^{1}$ Email: p.mcaleer@hull.ac.uk
} 
Today Bakhtin's theories remain relevant to Latin American literary studies, especially in the area of the neo-baroque and the grotesque. What has been questioned, however, is the degree to which comedy can be subversive. Umberto Eco neatly sums up this theoretical perspective. The liberating aspects of comedy, he says, "can exist only if a background of unquestioned observance exits" (1987, 275). Transgressive laughter paradoxically depends upon the dominant social codes that it purportedly challenges.

A more expansive view of the function of comedy in CAS requires us to take into account both its corrective and subversive potential. Gemma Roberts (1976) has examined the darker and castigatory comic impulses which are aimed at the novel's bizarre characters. Her article suggests that the Buendías are depicted as eccentric others. However, written before the advent of postcolonial theory, it does not attempt to study the ways in which the novel's neocolonial context shapes the interpretation of these comic characters. The works of Edward Said ([1978] 2003), Homi Bhabha (1994) and Walter Mignolo (2000; 2007) have highlighted the discourses and strategies of power at work in the representation and interpretation of otherness. Susan Purdie's (1993) psychoanalytical theory of comedy shows that joking about others shares the same impulses of desire and anxiety as those that Bhabha identifies in the construction of stereotypes. These unconscious impulses, both theorists argue, feed directly into discourses about the "other," and the discursive frameworks that underpin them: the idea of a European and non-European identity, for example. A combination of Purdie's theory of comedy and postcolonial theories of othering, therefore, opens the novel's comedy to a new reading. It reveals the ways in which the comic strategies used on the characters of CAS function as jokes about the "other." It also enables us to reflect on how these jokes enter into a dialogue, to use Stuart Hall's term $(2013,235)$, with certain discourses of power, which uphold gender and ethnic binary divisions: male/female, normal/abnormal, centre/periphery, West/non-West, etc.

Of course, it is not my intention to propose that the novel is purely comic. Many of the characters display tragic characteristics, and, while the emphasis of this article clearly falls on the comic aspects, it does not ignore the tragic ones. Neither is it my intention to suggest that the following reading(s) of the comic characters in CAS were necessarily the product of GGM's intent. The author probably intended the allusions to stereotypes to be read as a parody of (mainly) Western discourses about the "other," just as Gerald Martin (1989) argues that the themes of solitude and incest are parodic deconstructions of the racial theories expounded by Carlos Octavia Bunge, and others. However, according to Linda Hutcheon (1989, 101), parody is an extremely complex and ambiguous rhetorical strategy which 
provokes multiple readings that often contradict the "preferred message" of any text. The meaning(s) of parody in CAS, as we shall see, are made yet more diffuse not only by the subtleties of the metafictional games involved in deconstructing such neo/colonial discourses, but also by the comic techniques of exaggeration used to lampoon them. These two aspects, along with parody's innate ambiguity, I argue, open up the novel and the comic treatment of its characters to numerous interpretations, which depend on the reader's political, gendered, and cultural position within global and local discourses of power. Its international success (Bell-Villada 2002, 2), especially in the United States and Britain, at the very least indicates that it has been interpreted differently across different geographical and discursive fault lines. Indeed this article examines whether the novel's global popularity is partly dependent upon this multiplicity, which allows readers the pleasure of either confirming or subverting certain neo/colonial discourses. But first let us take a closer look at Purdie's theory.

Drawing on the register theories of incongruity outlined in several works (Bakhtin 1981; Attardo 1994; Koestler 1967), Purdie (1993) proposes that comedy stems from a transgression of the rules of language. Language depends on difference and, when two words or two separately categorised registers are incongruously combined with comic effect, the rule is transgressed. This function of comedy, furthermore, is intrinsically linked to Lacan's model of the unconscious mind. According to Lacan, in the pre-linguistic Mirror Phase the child experiences a state of "completeness" thanks to its identification with the mother, who it sees as an extension of itself. This sense of "oneness" and "plenitude" is in fact illusory because the child's identity is dependent on the mother, who may leave the child alone, which creates a pattern of desire and anxiety. The child then enters the Symbolic realm through the acquisition of language. This transition from the Mirror Phase (the illusory sense of oneness with the mother) into a linguistic system of differences (the Symbolic Order) is so traumatic that it is suppressed, thus creating the unconscious. This circuit, which is driven by the longing to return to the illusory non-difference of the Mirror Phase, underpins all human behaviour. Every human enunciation and action is a sublimated expression of this desire, which can never be fulfilled, and which paradoxically is the motor of our conscious existence.

Thus Purdie $(1993,35)$ claims that comic incongruities, the compression of different registers, words or images, are an important expression of our deep-seated desire to return to the pleasures of this former pre-linguistic state. This argument is not so different to Freud's observation ([1905] 2001) that the incongruities of comedy share similarities with the functioning of the unconscious mind, in which disassociated ideas and images are also 
compressed. Freud concludes, therefore, that the psychic pleasures of comedy and laughter are a resurfacing of the repressed desires that reside in the unconscious. In the Lacanian model such articulations are understood as sublimated expressions of our yearnings to go back to a state of non-difference, which, as we have pointed out, is illusory. Joking, like any human utterance or action, is driven by such desires and, at the same time, haunted by the impulses of anxiety associated with them.

Employing Lacan's paradigm of transition, Purdie then observes further patterns of human behaviour in which comic expression plays an important role. Just as the infant is dependent on the mother for its identity in the Mirror Phase, in the Symbolic realm individual identity is "constituted only as the object of another's attention" (Purdie 1993, 28). For Lacan $(1977,58)$, in order “to be we require an other's gaze and recognition of our own desire." For Purdie, joking, a term she uses to refer to all types of comic episodes, follows this pattern. The success of all joking depends on the reaction of the narratee or listener. It is the laughter of the reader/listener that confirms our ability to transgress the Symbolic Order of language. The successful reception of the joke forms a semantic relationship between the teller and the listener that "allows an unusual and potent joint subjectivity" (Purdie 1993, 5). It is this collusion that confirms the joker's agency. All joking discourse, Purdie states, involves an “'ab-use' of language through whose exchanged marking we claim mastery of Symbolic competence" $(1993,55)$.

Purdie's theory identifies important aspects of comic expressions. Firstly, the impulses involved in joking stem from the repression of fundamental drives. Thus "[j] oking confirms our ability to hold on to Symbolic operation in the same moment as it allows a 'play' of the energies which militate against that" $(1993,35)$. The act of joking stimulates our repressed drives to return to the illusory oneness of the Mirror Phase, which means that it is caught up in both the anxieties and pleasures associated with this desire. The importance of Purdie's observation will be revealed later in this article when we discuss the points of contact between her theory and Bhabha's work on stereotypes.

Secondly, in the linguistic sphere of the Symbolic Order, these impulses are channelled into the linguistic play of joking through which the joker acquires an individual identity. This concept is not based on the traditional humanist notion of identity or author. Rather it is understood, along the lines of sociolinguistic theory, as an utterance whose meaning(s) is/are dependent on a "received reception" (Purdie 1993, 30). Therefore, like any utterance, the success and meaning(s) of any joke lie with the audience or reader. 
Finally, according to Purdie, the psychic impulses of pleasure, aggression and anxiety at play in joking are just as likely to be channelled "in the service of entrenched power" (1993, 126-7) as they are of being oppositional. This is especially the case with jokes about others, which follow a well-defined technique. In such examples, "all joking objects, the apparently wholly low as well as the evidently high, are perceived as holding some kind of power over the jokers, and it is funny when they are suddenly perceived as not having it" $(1993,66)$. Jokes about others, therefore, are quite obviously caught up in existing social equations of power.

Let us now examine the comic techniques employed in CAS in reference to its characters. José Arcadio Buendía is the founding father of Macondo, with its clear biblical associations, whose scientific experiments are truly prodigious, yet they always end in comic disaster since they are informed, tellingly, by a miscomprehension of objects of modernity: the telescope, the magnet, and the daguerreotype with which "había resuelto utilizarlo para obtener la prueba científica de la existencia de Dios" $(2000,10,12,71)$. These examples fit neatly into Purdie's appropriation of Bakthin's and Attardo's linguistic congruity theory. In the passage cited, separate socio-linguistic codes of the scientific and the spiritual are comically placed together. However, the comedy is not just a ludic play on language and concepts. The biblical founder of Macondo, a reference to symbolic power, is reduced to a comic fool, since his unbridled imagination always leads him to misuse tools associated with Western progress and rationality.

The following episode, in which José Arcadio (son) returns home, is perhaps a more recognisable comic moment due to its scatological nature. It begins with a typical use of exaggeration. Due to the sheer size and strength of José Arcadio (son), the Buendías "tuvieron la impresión de que un temblor estaba desquiciando la casa" $(2000,113)$. The dramatic arrival of this outlandish giant is brought down to earth some pages later when we learn that his "ventosidades marchitaban las flores" and that José Arcadio earns money by raffling "su masculindad inverosímil" at the local bar (2000, 115-6). Here, registers associated with the prodigious and indeed threatening seismic event of an earthquake are brought low by their combination with the scatological.

Other comic moments involving the males of the Buendía clan follow the same pattern. El coronel Aureliano Buendía, for example, earns the reputation of being the most feared revolutionary soldier, who instigated thirty armed uprisings, but ludicrously lost them all (2000, 129). Aureliano Segundo's hyperbolic success in animal husbandry is undercut by its implied dependence upon his love making with Petra Cotes $(2000,304)$ as well as his 
Rabelaisian frivolity, which eventually leaves him with nothing (2000, 404-5). Almost all the principal male characters are bestowed with symbolic power, via reference to mythical, religious or heroic narratives and/or natural forces, which is then shown to be vacuous.

Women of the novel receive similar comic treatment. Úrsula, who Bautista $(1989,98)$ identifies as the symbolic mother and matriarch of the Buendía clan, is the most positive female character of the book. She is capable of feats that her husband is not: providing an income and linking Macondo to the outside world. However, she is also victim of the same kind of ridicule. An example of this is her comically conservative reaction to José Buendía Arcadio's belated "discovery" that the world was round like an orange $(2000,13)$. Remedios, la bella, in turn, is depicted as a mystical creature whose beauty is not only unrivalled, but "no era un ser de este mundo" $(2000,239)$. These mythical and religious connotations are symbolic representations of power; yet, in the famous ascension scene, her otherworldliness is brought low via a comic association with bedsheets, as well as the inference that she is mentally retarded $(2000,240)$. Fernanda del Carpio, educated to be a queen, attempts to maintain the facade of aristocracy among the Buendías, but her antiquated pretensions are continually subject to ridicule.

These characters are more complex than such comic moments imply, and many are, of course, embellished with tragic features, which I shall deal with later. Nevertheless, all of the above examples, and many more, follow the strategy and technique of joking about the "other." This type of joking has been associated with the pleasurable sublimation of aggression and the elation of superiority (Bergson 1911; Hobbes [1651] 1968). Freud (2001, 103) identifies the suppressed aggression and desires of the unconscious mind as the source of all comedy. Purdie, in turn, testifies to the importance of these impulses in joking about others. It entails 'the destructive exercise of power over others, in a culture where 'power' is primarily understood as identical to aggression" $(1993,8)$.

But who is the "other" represented in these comic episodes? Who are the implied readers of these jokes? Or, in other words, who is the "us" who is invited to laugh at "them"? And what discursive constructs of social power are at play here? It is certainly not enough to presume that they are hermetic and/or innocent literary creations since, as theorists such as Edward Said (2003) and Raymond Williams ([1958] 1983) have shown, no such thing exists.

One viable answer to these questions can be found in the ways in which CAS intersects with discursive constructs about Latin America. James Higgins (1990) and Gerald Martin (1989) were the first to identify the historical patterns of the novel. Briefly summarising this argument, the founding of Macondo parallels the chronicles of the "discovery" and 
colonisation of the New World, while the rise of the Buendías echoes the emergence of the powerful landowning oligarchy, who, after the winning of independence, cemented the interests of a small "white" Creole elite as well the economic and cultural dependence of the region on Europe and later the United States. Perhaps with this reading in mind, Carlos Fuentes $(2011,268)$ and Vargas Llosa $(1971,56)$ argue that the novel lays the blame, in part, for the region's problems at the feet of Latin Americans.

Interpreted in this way, the comic episodes are satirical arrows fired at the oligarchic class that governed "badly" certain Latin American countries. Such a reading clearly fits into the carnivalesque approach of Parrilla Sotomayor (2002, 43) who proposes that the novel's comedy opposes the dogma of Catholicism, traditionalism and the imperialism of the United States in Latin America. Here, the possible implied reader of these episodes is interpellated into de-crowning the oppressive institutions and traditions that have "suffocated" and "damaged" the potential of the region. According to Schelling (2000, 12-3), modern Latin American political discourse is almost always debated within the parameters of this type of conflict: between the popular and landed classes, as well as the influences of neo-colonial powers.

This reading is arguably a more localised political one, more likely to be recognised by those with a local or academic knowledge of this historical narrative. However, can we say the same about the women characters? Gloria Bautista $(1989,103)$ concludes that the female archetypes of CAS could be taken as four aspects of the multifaceted Latin American women. In other words, GGM chooses to paint women using only four models of womanhood (the mother, the wife, the prostitute and the virgin), and within quite a narrow and stereotypical set of positive and negative characteristics; among them, fertility connected to domestic entrepreneurism, love, generosity and compassion, while on the negative side: bitterness, selfishness, conservatism, ignorance, and objectified eroticism. Who is the implied narrator of jokes about women portrayed in this way? It is of course possible to read some of them, as does María Elena de Valdés (1990), as, if not a direct criticism, then a laying bare of $19^{\text {th- }}$ century patriarchal discourse and the damage it inflicted on females. But what about the minor female characters who, through an "imaginación rabelesiana," are portrayed as "sierva[s] natural[es] de los apetitos varoniles" (Marcos 1989, 92)? Even the stronger characters, such as Úrsula, are ridiculed for having characteristics that come very close to being sexist stereotypes: the pious, conservative mandona. It is quite justifiable to claim that certain readers will interpret these jokes through patriarchal codes which are invested with sublimated "pleasures" of aggression and desire as well as those of gender hierarchy. 
Another discourse with which the novel interacts, in a more subtle but nevertheless clear manner, is that of race. López-Mejía examines the role of racial dynamics in CAS, and how it reflects the narratives of social hierarchy and legitimacy in Colombia. She argues that the minor female characters are a "distressingly predictable association of black women with hypersexuality and [...] infantilised sexuality" $(2013,35)$. The Quevedesque descriptions of these women are clearly charged with racial and stereotypical overtones of animality and objectified eroticism. For example, Negromanta is described as "una negra grande con huesos sólidos, caderas de yegua y tetones de melones vivos" and "una perra brava" (2000, 458-9). The indigenous guajiros and the gypsies are also painted through a familiar lens of servitude and exoticism (López-Mejía 2013, 32).

In contrast, according to López-Mejía, the Buendías represent the pseudo-European discourse of identity adopted by the criollo oligarchs, with their obsession for racial "whiteness" and their yearning to be associated with the "Western" myths of economic "aspiration and enterprise" $(2013,30)$. Thus, there is a constant stream of motifs in the novel in which "racial mixture most often intersects with illegitimacy" $(2013,29)$.

However, as we have seen, the Buendías also receive their fair share of ridicule. Many of their "Westernised" traits - Aureliano Segundo's enterprise or José Arcadio Buendía's rationality, for example - are undercut by a comic, and sometimes tragic ineptitude. On top of this, the novel hints, on several occasions, to the mestizo origins of the Buendía clan. As López-Méjia $(2013,31)$ admits, the physical characteristics of the family: "cabellos lacios" and "piel parda" $(2000,50)$ are associated in Colombia with indigenous and African ancestry. Moreover, the letter that accompanies Rebecca, who is more explicitly of indigenous origin, since she speaks an indigenous language, hints at the Buendías' ancestral connection with the guajiros, also known as the Wayuu, even if José Arcadio and Úrsula have conveniently forgotten it $(2000,56,42)$. Finally, the plague of forgetfulness, given that the disease is associated with the indigenous servants, Visitación and Canure $(2000,52,38)$, can be read as a metaphor for the "deliberate" forgetting of this racial and cultural ancestry, which, in turn, echoes the racial and social discourses employed by the oligarchic classes of many Latin American countries in the $19^{\text {th }}$ century. Hence it is quite possible to contend that the novel highlights through irony the hypocritical and mythical nature of such claims to "whiteness," rather than simply reiterating them, as López-Mejía's article implies. This hypocrisy is further highlighted by the arrival of the North American Banana Company which, as LópezMéjia $(2013,39)$ acknowledges, “introduces different gradations of whiteness in Macondo." 
What her article tells us is that CAS is infused with the racial and social issues that, according to Walter Mignolo (2000, 283-5; 2007, 164) and Vivian Schelling (2000, 9), have moulded constructions of identity and social hierarchy across Latin America and its relationship with the world. The presence of these discourses poses a further question about the representation and comic treatment of the Buendías. As we have indicated, these characters are depicted as the "other" in the jokes studied above. What, then, are the possible interpretations of such jokes in relation to these discourses of race and hierarchy?

It is certainly interesting to note at this juncture that the content of the jokes and the depiction of the Buendías recall certain discourses and stereotypes that are embedded in Western and/or Westernised narratives of the "other." Within the Western tradition, Stuart Hall ([1997] 2013, 247) defines stereotypes as the reduction of a group of people to a number of traits that "exaggerate and simplify them" in order to fix and essentialise difference; for Hall, "stereotyping deploys a strategy of splitting. It divides the normal and the acceptable from the abnormal and the unacceptable." Said (2003) and Bhabha (1994), although focused on the Orient and India respectively, reveal how these discursive strategies have shaped the power dynamics between the West and the "other" in more global terms. ${ }^{3}$

These constructions and their continual reproductions are deeply ingrained in the discourses of modernity and the Enlightenment, in which the West comes to represent itself as dynamically "rational, developed, humane, superior," and the "other" as statically "aberrant, undeveloped, inferior" (Said 2003, 300), as well as grotesque, irrational, insane, aggressive, debauch and despotic. At the other end of the spectrum, the European Romanticists tended to represent the non-Westerner through the lens of exoticism, spirituality, sensuality, sublimity and, in some cases, with feminine or childlike qualities, worthy of paternal empathy.

Schelling $(2000,9)$ confirms that mainly Western texts which have attempted to delineate the ontological nature of the region have tackled the subject through similar binaries. These texts are also informed by a similar transference from traditional to modern secular theories of race which Said observes in Orientalism. ${ }^{4}$ In general agreement, Mignolo (2007, 164; 2000, 21) proposes that the very idea of "Latin America" is not only a construct of Spanish colonial discourses of race but also (and more so) of the "chosen" and "independent" later discourse of latinidad, which, due to the rise of Anglo-Saxon modernity and North-American neo-colonialism, relegated "Latin America" and its citizens to a second class (and race) within the world order. Another strand of this tapestry has been written by Latin Americans who, nevertheless, have adhered to Western paradigms, in which the lettered Westernised 
city symbolises the "civilised" centre and the interior/rural locations, the "uncivilised" periphery. They are the dominant grids and codes through which Latin Americans represent themselves and through which they are portrayed and understood by others within "the imaginary of the modern world system" (Mignolo 2000, 287).

Many stereotypes exist about the region we call Latin America. Some stem from the colonial imaginary of the Discovery and Conquest. The innocent/childlike and/or the barbarian/cannibal imaginaries of el indio, a staple image of the chronicles of the $16^{\text {th }}$ and $17^{\text {th }}$ centuries, continue to resonate into contemporary discourses..$^{5}$ The poor uneducated "Latin American" suffering at the hands of the nefarious colossal of the North, for example, or the dangerous "Tin Pot" dictator, of which Hugo Chávez was the latest embodiment on American Fox News. The exoticness of the "Latin American" is another stereotype linked to the metaphors of paradise found in the early European narratives about the New World, of which the holiday brochures of today for Latin American destinations, the coverage of the Rio de Janeiro carnival, and the recent eroticisation of Brazilian women on T-shirts during the build up to the 2014 World Cup are the most obvious continuation. Finally, these stereotypes are intricately and inextricably tied up with an overarching discourse that permeates almost all the narratives about the region: its "backwardness," in comparison to the "developed world" of Europe and the United States. ${ }^{6}$

It is not my intention to exhaust a list of stereotypes about "Latin American" identity here. I am sure many more occur instantly to the reader (whether "European," "North" or "Latin American"), so deep has been their permeation in the fabric of discourses about the region. My aim is only to emphasise that some of these stereotypes relate to not only the depictions of the minor indigenous and black characters, but also to the Buendías. In fact, if we look again at the comic techniques and images, examined above, we can see that the Buendías slide between the two poles of these portrayals. José Arcadio Buendía contains elements of the archaic and spiritual stereotype, in the sense that he is the founding father and proto-male of Macondo, while, at the same time, he is represented as comically "backward" and "naïve" in his understanding of science. The depiction of Remedios, la bella, follows a similar pattern. Her character oscillates between sublime exoticness and insinuations of mental retardation. Aureliano Segundo's implausible ability to multiply his livestock displays parallels with an historic stereotype about the region: its "boundless riches," which is connected to "la ilusión de una imagen de Jardín de Edén" (Guadalupe Vargas 2000, 235) that Alexander von Humboldt and others wove into the idea of "Latin America." At the other 
end of the scale, the character's profligate frivolity fits into one of the more general stereotypes listed above: the debauch "other."

Aureliano Buendía is the irrational aggressor, given the thirty senseless wars he wages, who nevertheless has a rather sterile impact on the world. This failure could and should be seen as a more general comment on the futility of the Civil Wars that plagued Colombia in the $19^{\text {th }}$ century. However, while it is not part of the same comic episode, we are also told through Úrsula, when in a state of enlightenment, that no "había hecho tantas guerras por idealismo [...] sino que por pura pecaminosa soberbia" $(2000,299)$. As Santagio CastroGómez observes $(2010,79)$, "la altanería" is a well-known stereotype of the mestizo, mulato or black or indigenous "other," which stems from colonial times.

José Arcadio (son) is painted in terms of the hyperbolic macho, a clear Latin American stereotype, whose virility is reduced to stock scatological and grotesque images of the "other." Interestingly, Said $(2003,314)$ and Hall $(2013,263)$ assert that, quite often, in the fantasies of the Western mind the potentially threatening stereotype of the virile and/or aggressive male "other" was (and still is, in some cases) tamed by references to an inability to produce an instrumental effect on the world, which is embroiled in the stereotypes of the childish or perverse "other." The joking aimed at José Arcadio (son) and Aureliano Buendía implies their incapacity to realise a tangible impact on the fictional reality of the novel, which, in a sense, mirrors the development of their characters. The Buendía men's descent into solitude and bitterness emphasises the sterility of their personalities and legacy. This is a thread we shall pick up on again in the section on tragedy in reference to the trope of the child.

Of course, the imagery used in these depictions are examples of GGM's well-known technique of hyperbole. The stereotypes from which many of the Buendía's traits derive are made freakish by their very exaggeration. This technique suggests an attempt at parody. The stock representations of the West's "other" are overblown and lampooned, and, therefore, potentially subverted. Yet we must ask ourselves, to what extent can one exaggerate images that, according to Hall (2013) and Said (2003), are already exaggerations? And what effect does exaggerating an already exaggerated characteristic have? Hall $(2013,252)$ highlights the inherent risks in such strategies. Examining examples of black men's oppositional adoption of hyper-masculinity and super-sexuality in the United States, which are meant to function as a caricature-in-reverse, he concludes that such tactics only served to confirm the fantasy/fear of the white imaginary. Moreover, the exaggeration of difference (of freakishness, of 
bizarreness, etc.) is an inherent feature in the West's archive of the "other." Parody employed in this way, then, is problematic. Its effect is, at best, ambivalent.

The ambivalence opens up the author's comic treatment of the characters to a different interpretation. In Hall's view $(2013,235)$, all such representations of the "other" unavoidably form an intertextual relationship with previous images and ideas (i.e. associated stereotypes) over which the author and text have little, if any, control. It is quite possible, then, for a reader discursively positioned in, say, the United States or Britain or Europe to interpret these humorously exaggerated traits through the colonial and neo-colonial grids and codes on which, according to Mignolo, the very idea of "Latin America" is based. Or, in other words, the comedy can be construed as confirming such discourses, rather than challenging them. André Jansen $(1992,719)$, for example, observes that this type of comedy in CAS "consiste en presentar algún defecto humano tal como la indolencia o la apatía, tan frecuentes en Iberoamérica, como si fuesen una enfermedad epidémica." Jansen here not only unconsciously accepts a prevalent stereotype of the Latin American "other," the "lazy Hispanic" or "indolent mestizo", he also has no problem in interpreting the novel's comic exaggeration as a criticism and, therefore, confirmation of such a trait; or is it illness?

It could be said, of course, that one would have to be a particular type of European or Western reader to experience the jokes in this way. But this is not necessarily the case. ${ }^{7}$ As Ángel Rama $(1984,14)$ points out, the imaginaries of the different Latin American nations are constructed upon an opposition between the lettered city (i.e. Westernised values) and the savage or exotic space of the "other" (the world of el indio or mestizo). ${ }^{8}$ Sarmiento's essay Facundo (1845) on civilisation and barbarism is the most well-known formulation of this narrative, the polity of which continues to be defined as a contemporary type of internal colonialism (Anzaldúa 1987, 7; Mignolo 2000, 284; Altschul 2012, 13-20). Similar stereotypes to those already identified have permeated and continue to permeate the discourses about the "other" in different Latin American nations: the mestizos, indigenous and African peoples. One only has to read Rómulo Gallegos’ Doña Bárbara (1929) or listen to a joke in Argentina about los bolitas, which is a derogatory term used to insult the more indigenous-looking Bolivian migrants. ${ }^{9}$ Again, there are many more examples that no doubt will occur to the reader. We can conclude quite safely that the majority follow the pattern established by neo/colonial discourses: the backward, uncivilised savage or the exotic childlike, telluric "other."

It is important to remember here that the reader is invited to identify the Macondo of CAS with the region surrounding Aracataca. The banana massacre episode and the presence of the 
United Fruit Company are both well-known historical and geographical markers. In general terms, Macondo is clearly meant to represent some kind of "backwater" which is cut off, for a time at least, from Western modernity. Is it impossible, then, to imagine that a "Westernised/urbanised" "Colombian" or "Latin American" might plug into the type of ideological power that upholds an apparatus of internal colonialism to interpret and enjoy the jokes and comic stereotypes of the novel?

It is interesting to note at this point that there are intrinsic links between the psychological impulses of comedy identified by Purdie and those of stereotyping. Homi Bhabha (1994) collates the psychic economy at play in stereotyping with that of the Scopic drive, fetishism, and Lacan's schema of the Imaginary. For Lacan, the Scopic drive is the function of the desires that govern the way in which the human subject constructs its subjectivity. In this process the human gaze identifies the self with an object, which alienates the subject from itself. The gaze sets up a paradigm in which we search for the satisfactory pleasure of subjectivity in the other which can never be completely fulfilled. The process is informed by the child's disturbing realisation of sexual difference, or any kind of difference. Identifying the self with an other, who is of a different sex, for example, creates the psychic circuit of an unfulfillable desire (for full subjectivity), while, at the same time, stimulating the anxieties that stem from our transition into the linguistic world of differences. Bhabha employs this model in his theory of the stereotype/fetish. The stereotype/fetish is both an expression of the desires of the gaze and simultaneously an attempt to disavow the fear aroused by the recognition of difference (sexual in the Oedipal Phase, cultural/racial in the neo/colonial stereotype). Finally Bhabha locates all these impulses within Lacan's Imaginary. In short, they are bound up in the desire to return to the plenitude of non-difference of the Mirror Phase. However, because in the Mirror Phase the subject must recognise itself through discreet images which are simultaneously alienating and possibly threatening, the repositioning of the desires associated with it in relation to cultural difference (skin colour, race, culture, for example) is inherently problematic: "like the mirror phase, the 'fullness' of the stereotype - its image as identity - is always threatened by lack" (Bhabha 1994, 110). The fixity of the neo/colonial stereotype is an attempt to mask/invigilate/control the difference of the "other," which always escapes that construction and, therefore, requires constant reinforcement.

We have found similar psychic sources in joking and laughter. Joking is an attempt to master discourse and a potent tool that momentarily confirms individual agency. It is also informed by the desire to return to the illusory fullness of the Imaginary. The act of joking is 
driven by our repressed impulses to return to the Mirror Phase, and, therefore, it is simultaneously haunted by the anxieties and aggression that stem from this pre-linguistic state. Like the stereotype, then, joking is as much predicated on mastery and pleasure as it is on aggression and anxiety. One need only add the ingredient of the Butt of the joke (the objectified, different "other" constructed as image) in order to appreciate that the psychic circuitry, source and impulses that shape the stereotype are also at work in jokes about others. It is easy to see, then, how they might be stimulated simultaneously towards the same object with similar effects, which of course they often are. Indeed, if we invert Henri Bergson's observations (1911), we can interpret such jokes as an attempt to impose rigidity onto the "other," rather than as examples of ridiculing the rigidity of an other.

The link between the impulses of pleasure and anxiety of joking and stereotyping becomes more compelling when we take into account that Purdie also notes the paradigm of constant repetition when joking about others. She proposes that othering people through jokes requires constant reinforcement since the "power/threat they pose is that of escaping this construction" (Purdie 1993, 66). It is timely to remember here that almost all the characters of CAS either tragically or comically repeat their "aberrant" behavioural traits throughout the novel. We are even told that the ensuing generations inherit the defects and exotic abilities of their forefathers $(2000,221)$.

Furthermore, both Purdie and Bhabha recognise the intrinsic link of joking and stereotyping with the employment of instrumental and ideological power. For Purdie (1993, 147), joking "seizes ideological power and constructs and confirms socio-economic power." While Bhabha $(1994,111)$ observes that the neo/colonial apparatus of power is shot through (indeed formed by) the same impulses referred to above. Given the shared source, conflictive impulses and similar functions of joking and stereotyping, it is plausible to argue that, when such psychical forces are aroused within the reader/audience by comic references to stereotypes, they are potentially rechannelled through the discursive fields with which a naturalised association has been established. In other words, the psychical energies at play in joking about stereotypes flow into the discursive constructs of ideological power (cultural confirmations of superiority, for example) that already exist, which is part and parcel of the collusive sensation of pleasure and power experienced by teller and listener.

As we have indicated, the ambivalence of the parodic exaggeration employed by GGM makes this kind of collusion possible between the text, the reader, and the discursive constructs that permeate the idea of "Latin America." Purdie's model emphasises the symbolic mastery of the author. However, in a reading experience the author is obviously not 
present in order to undergo such a semantic and ideological collusion. The complicity exists between the text and the reader, which stimulates an experience of "identity" in the latter. On a linguistic level, the reader recognises the semantic transgressions of the jokes in CAS, which marks his or her Symbolic competence. On a discursive level, the reader both recognises and is recognised by the discourses of power which frame the jokes' possible meanings. Hence the process bestows the reader with a potent feeling of pleasure.

Yet, at the same time, the process is haunted by impulses of anxiety. The gratification derived from humorous semantic incongruities, according to Purdie (1993, 35), is directly related to our deep-seated unconscious desire to return to the Mirror Phase; to a state of nondifference. The threat of lack (of the absent mother), inherent to the source of this desire, also shapes the representation of the "other" through the fetish of stereotyping. In this respect, joking about the "other" in CAS stimulates a number of effects. It momentarily allows us (the reader) to mark a semantic and discursive identity, yet this marking is caught up in, and threatened by, our fascination with, and fear of, the strange and different.

Of course the novel is more than the jokes we have analysed in this article. CAS also contains aspects of tragedy. Its tragic themes, the solitude of the characters and their inability to break free from a cycle of despair and futility, have been the focus of an industrial quantity of readings. From a certain perspective, they align the characters with Western antecedents of high literature and so-called "universal" themes, such as metaphysical pessimism (Shaw 1991, 220-1). Yet neither are these themes, along with the symbols and archetypes used to create them, necessarily innocent or culturally neutral.

Gary Eddy (1990, 107), for example, employs the archetypal theories of Jung and Neumann to examine the relevance of uroboros, "the symbol of the ego immersed into the unconscious," to the characters. He notes that the mother archetypes "act like a gravitational field" whose "recurrence represents the rise to consciousness of the uroboros" which "shows that the child cannot grow up" $(1990,110)$. Thus, the male characters are trapped in a primordial and child-like state by the matriarchal forces. As interesting as this reading is, it becomes problematic when we take into account the novel's clear allegorical associations with the imaginary of "Latin American" history and identity. In neo/colonial discourses, the West has continually written about itself in terms of being more developed, rational, more adult in comparison to the neo/colonised "other," who is irrational, feminine and childlike. Moreover, the Buendías' tragic characteristics and final demise display all sorts of parallels with other neo/colonial discourses. The Buendías, as we have shown, are represented as mestizos and the tragic mulatto is a stock character in United States cinema (Hall 2013, 239). 
The tragic aspects also correspond to the myth of the tristeza criolla, which became a kind of internalised, Latin American neo-colonial discourse in the early twentieth century. ${ }^{10}$

Eddy also reveals something about the complex yet thin dividing line between archetypes and stereotypes. According to Robert L. Sims (1990, 103), the building blocks of the characters in CAS are the patriarch, the warrior hero, the great mother, among others. These archetypes are the nut-and-bolt elements common to all examples of storytelling. Richard Dyer $(1999,246)$, on the other hand, proposes that in individual texts such basic components are always layered with different symbolic values which define characters as either social types or stereotypes. The social type, Dyer observes, differs from the stereotype because it is a representation of those who belong to a certain society, and because of its potential flexibility. The stereotype, in contrast, is a representation of the "other," who does not belong and whose traits are fixed. As we have seen, the "universal" aspects of CAS's characters are overlaid with other traits, some of which are invested with patriarchal or sexist codes, others of which correspond to certain neo/colonial stereotypes: their exotic otherness, bizarreness and repetitive behaviours. Others, of course, transcend these codes with a delineation of more positive attributes: José Arcadio Buendía's leadership and Úrsula's enterprise, for example. But even in such instances the novel's comedy and tragic themes often undercut the symbolic value of these characteristics.

At the same time, from a more local or informed reading, these features can be placed in the category of social types: as a satire of the tragic latifundista buffoons that Carlos Fuentes and Vargas Llosa identify. Dyer claims that this kind of uncertainty marks the relationship between the social type and the stereotype. The distinction between the two is "one of degree" (Dyer 1999, 247) and, often, very hard to draw because social categories overlap: men who belong and "black" males, who do not. This inherent ambivalence is particularly relevant to CAS not only because of the comic and tragic treatment of its characters, but also because it is a novel that is constantly being read in different geographical and discursive spheres. The degree to which the characters are or are not interpreted within the realms of stereotyping or social typing depends on the ways in which the readers' discursive positioning (nationality, class, gender etc.) informs their responses to them.

The novel's ambivalent treatment of its characters through comedy and tragedy poses an interesting question about its success. Gerald Martin (1989, 225) writes: "The most likely explanation for [the novel's] sensational success in, say, Britain or the US is that its subtle ambiguities make it possible for readers to despise or sympathise with its Latin American characters as it would be in real life outside the novel." This observation suggests that the 
ambivalence created by GGM's parodic treatment of the "other" is one of the (admittedly many) sources of pleasure to be derived from CAS. In simple terms, certain readers are allowed to indulge in the frissons of fantasy and fear that they have been taught to associate with the othering of "Latin America" or, in a more regional reading context, of the interior and non-Westernised Latin American "other." Obviously, as we have discussed, the "preferred reading" of the parody may well be grasped, which provokes a different interpretation. One that seeks to subvert this hierarchical equation. The local satirical reading of the latifundistas is yet another possibility. Nevertheless, these interpretations do not rule out the aforementioned reading experience. They all exist side by side and are an example of what Hall $(2013,251-60)$ identifies as the circularity of power: the inability to fully subvert and escape established discourses of the "other." In fact, the commercial success of CAS and other so-called ethnic novels - Salman Rushdie's Midnight Children (1981), Vikram Seth's A Suitable Boy (1993), and Monica Ali’s Brick Lane (2003), to mention a few - may well depend on this circuit. They all, in different but similar ways to CAS, attempt to subvert and parody established representations of the "other," yet their commercial and literary allure is all too often contingent upon an exotic image on the front cover, the ethnicity of the characters, as well as their author's ability to "capture" a defamiliarised, different view of the world. ${ }^{11}$

Unsurprisingly, the same ambiguity and contradictions plague the question of the authorial voice in CAS. Philip Swanson $(2010,58)$ has opined that the implied narrator of the novel invites an implied reader of the First World, who is invited to enjoy or mock their exotic, magical perspective. The scene in which José Arcadio Buendía mistakes ice for a diamond is a case in point. This much discussed episode could be interpreted as a mockery of the character's rural naivety. From another perspective, it is quite possible to identify this as an attempt to describe the world from what has been called the logic of a local point of view: in other words, from the point of view of a community that has never seen ice before (Hart and Ouyang 2005, 3). ${ }^{12}$ This vision is constructed, in part, through lyrical or even sublime language: "infinitas agujas en las cuales se despedazaba en estrellas de colores la claridad del crepúsculo" (2002, 8-9). Such a well-crafted sentence is, of course, an example of GGM's much-lauded literary skills, which I am not attempting to question here. Yet, as Said (2003, 46 , 118) observes, the West's imaginary has often depicted the "other"'s mentality as spiritual and/or sublime, as a more "poetic" mentality in comparison to the Newtonian one of the West. Thus, it is quite possible to interpret such episodes as a "Western" or "Westernised" implied author's attempt to describe the world through an exotic "Third- 
World" vision. In other words, despite GGM's insistence $(1982,63)$ on the influence of the "local" vision of Aracataca on his own particular brand of magical realism, the technique of defamiliarisation constructs an imagined (objectified?) "Third-World" view for the entertainment and satisfaction of a "First-World" reader.

Moreover, the argument that CAS's magical realism represents the logic of a community living in a pre-modern time warp is based on an overarching neo-colonial paradigm. Mignolo $(2000,285)$ shows that the modern notion of a linear temporal development that penetrates into the future, bringing with it enlightenment and progress, is "one of the most powerful strategies for the coloniality of power in the subalternization of languages, knowledges and cultures." It is a discursive version of "history" and "progress" written from a Western perspective that a priori places the neo/colonised "other" in a constructed past/present and subaltern position, which gave birth to generalisations like "a Third-World perspective."

This brings us back to the question of parody again. Gerald Martin (1989) focuses on the allusions made in the novel to certain myths of identity, some of which we have already discussed. He identifies allegorical links between, on the one hand, the themes of incest and the Buendía's genetic inheritance of bizarre characteristics, and, on the other, the discourses of the biological determinism expounded by Carlos Octavia Bunge to explain Latin American "backwardness" in the first half of the $20^{\text {th }}$ century. Martin proposes that the Biblical hurricane that destroys Macondo at the end of the book as Aureliano Babilonia deciphers Melquíades' parchments contains a political message. It deconstructs these narratives and highlights the need to look for new ones, inspired by the Cuban Revolution of 1958.

This reading is extremely compelling and I do not pretend to deny its validity. However, what we are talking about here is not comedy, but parody and irony combined with certain metafictional games. The technique employed is more akin to the type of humour that Umberto Eco $(1987,277)$ and Luigi Pirandello $(1960,130)$ define in their different works on the subject. It is a kind of humour that radically questions the narratives we use to give our lives meaning. ${ }^{13}$ Within this reading, the comic and tragic stereotypes become parodies of the tropes associated with the neo-colonial discourses of biological determinism, which should be seen as fictions. Arguably this is the author's intended reading. Does this mean, though, that every reader will interpret them in this way? Putting aside the fact that the ending logically requires the reader to re-read the relevant episodes, parody and irony are double-edged swords. Both are steeped in ambiguity since they express a double-coded meaning which both "legitimises and subverts" (Hutcheon 1989, 101) the discourses that underpin the 
meaning and value of the object parodied. It is, therefore, easy enough to misinterpret the "preferred message" of this type of irony and parody.

Moreover, the comic constructions and the techniques involved in joking about others are quite different from parody or the type of humour defined by Pirandello or Eco. They elicit almost automatic responses due to their transgression of the rules of language. The techniques of exaggeration used in these jokes also correspond to a powerful archive of representing the "other." Finally, the sublimated impulses of anxiety and desire, implicit to this kind of joking and stereotyping, are all too easily channelled into established narratives. As Purdie argues, joking is implicated in "self-perpetuating patterns of seized and accepted discursive power [that] operate, often quite unconsciously, in parallel and intersecting levels from the most intimate to the most institutional, from the most personal to the most culturally generalised" (1993, 169). Joking with stereotypical traits has, at the very least, the potential to reconstruct discourses of discriminatory power. Indeed part of the pleasure of enjoying such joking conceivably stems from the fact that the teller and/or audience are momentarily recognised and constituted by these pre-existing discourses. This is equally true from low and high joking positions.

Of course, it is possible to claim that in our current postmodern age, in which we are constantly told that the once relatively solid equation between the centre and the periphery (in its national, gender, racial and neo-colonial guises) has begun to unravel, the possible interpretations I have discussed would be less likely. However, as Judith Butler (1993, 227) observes in her study of gender, while positive re-appropriations of names like "queer" or "gay" in the late $20^{\text {th }}$ century have changed their significations, the terms remain infused with their once derogatory meanings. A similar historicity, it could be argued, still haunts certain stereotypes. Néstor García Canclini $(1995,110)$ complained, as late as 1995, that many academics have maintained a type of "fundamentalismo macondista" in which Latin America is fetishized as a pre-modern and sublime continent. And, while in the bubble of academia postcolonial and feminist theorists have deconstructed the neo/colonial and gender paradigms that deeply permeated the imaginary of the "other" until well into the $20^{\text {th }}$ century, this does not mean that all of today's general public have followed suit. It would be naive, I think, to believe that they have.

\section{Notes}

${ }^{1}$ Forthwith the novel will be referred to as CAS; the author will be referred to as GGM. 
${ }^{2}$ Emir Rodríguez Monegal's $(1985,6)$ comments are emblematic of this trend of thought: "Cien años de soledad and Tres tristes tigres take us back to the origins of Latin American literature [...]. This is the literature of a people on the lunatic fringe of Western civilisation [...], a people who attack their masters, both foreign and domestic in the only way they can, by laughing at them." Dianna Niebylski's study (2004) of the subversive and carnivalesque aspects of female Spanish-American fiction is the most recent expression of this perspective.

${ }^{3}$ See, for example, Said's $(2003,46)$ analysis of Henri Kissinger's essay "Domestic Structure and Foreign Policy." Here, Said observes, Kissinger draws the same lines between the Third-World countries, which specifically include Latin American ones, and the West as those traced by imperial orientalists.

${ }^{4}$ It is interesting to note that Julie Greer Johnson (1993) observes similar stereotypes in Spanish colonial literature about criollos, mestizos and Amerindians. This historical transference of stereotypes from one period to another shows quite clearly the overlapping of religious and secular "theories" of race as well as their interdependence.

${ }^{5}$ In Peru, for instance, legislation of the 1920s enshrined the indigenous populations as minors (Manrique 2000, 221).

${ }^{6}$ See, for example, the introductory comments of Renato Ortiz's article $(2000,127-46)$.

${ }^{7}$ José Guadalupe Vargas (2000, 233), a Latin American critic, states that CAS has contributed to the creation of myths and stereotypes of the Latin American people, and especially the paradigm of "backwardness."

${ }^{8}$ Rama (1984, 16-8 and 86-8) also identifies an ideological as well as an economic line of continuation that runs through the construction of colonial cities and into the discourses of modernization and independence in the $19^{\text {th }}$ century, some of the methods of which mirror those of Said's latent orientalists. His comments suggest that the construct of the "civilised," "dynamic" and "rational" urban subject and the "barbaric," "static," "irrational" other is a powerful discourse of individuation that operates at institutional and personal levels in narratives of Latin American nationhood.

${ }^{9}$ For an example of the use of this term, see Diego Gachassin's film Vladimir en Buenos Aires (2002), which explores the contemporary currents of Sarmiento's discourse of racial "theory."

${ }^{10}$ Donald Shaw $(1991,114)$ also identifies a possible prejudicial reading of the novel that comes dangerously close to this doctrine of Latin American racial inferiority.

${ }^{11}$ See the cover images on two English translations of CAS; specifically, the exoticised female on the Penguin edition (2007), or the paradisiacal image on the cover of the Avon Books edition (1970) published in the United States.

12 Philip Swanson $(1991,67)$ resumes this approach when he examines the possibility that a ThirdWorld perspective is able to subvert (within the confines of literature) the tradition of imperialism, and the exploitation of Europe and the United States.

${ }^{13}$ Donald L. Shaw (1991, 220-1) and Nicasio Urbina (1992) note the importance of this type of humour in CAS.

\section{References}

Altschul, N. R. 2012. Geographies of Philological Knowledge: Postcoloniality and the Transatlantic National Epic. Chicago: University of Chicago Press. 
Anzaldúa, G. 1987. Borderlands/La Frontera: The New Mestiza. San Francisco: Aunt Lute Books.

Attardo, S. 1994. Linguistic Theories of Humour. New York: Mouton de Gruyter.

Bakhtin, M. 1981. "Discourse in the Novel." In The Dialogic Imagination: Four Essays by M. M. Bakhtin, edited by M. Holquist, translated by C. Emerson and M. Holquist, 259-442. Texas: University of Texas Press.

Bautista, G. 1989. "El arquetipo femenino en Cien años de soledad." In Violencia y literatura en Colombia, edited by J. Tittler, 97-103. Madrid: Editorial Orígenes.

Bell-Villada, G. H. 2002. Gabriel García Márquez’s One Hundred Years of Solitude: A Casebook. Oxford: Oxford University Press.

Bergson, H. 1911. Laughter: An Essay on the Meaning of the Comic. Translated by C. Brereton and F. Rothwell. London: Macmillan Press.

Bhabha, H. 1994. Location of Culture. London: Routledge.

Butler, J. 1993. Bodies That Matter: On the Discursive Limits of Sex. London: Routledge.

Castro-Gómez, S. 2010. La hybris del punto cero. Ciencia, raza e ilustración en la Nueva Granada (1750-1816). Bogotá: Pontificia Universidad Javeriana.

De Valdés, M. E. 1990. “One Hundred Years of Solitude in Women's Studies Courses.” In Approaches to Teaching Gabriel García Márquez's One Hundred Years of Solitude, edited by M. E. de Valdés and M. J Valdés, 45-56. New York: The Modern Language Association of America

Dixon, P. 1986. “Joke Formulas in Cien años de soledad." Chasqui 15: 15-22.

Dyer, R. 1999. "The Role of Stereotypes." In Media Studies: A Reader, edited by P. Morris and S. Thornham, 241-8. Edinburgh: University of Edinburgh Press.

Eco, U. 1987. Travels in Hyperreality. London: Picador.

Eddy, G. 1990. "An Approach from Analytical Psychology". In Approaches to Teaching Gabriel García Márquez's One Hundred Years of Solitude, edited by M. E. de Valdés and M. J. Valdés, 107-15. New York: The Modern Language Association of America

Freud, S. [1905] 2001. The Standard Edition of the Complete Psychological Works of Sigmund Freud, Vol. VIII, Jokes and Their Relation to the Unconscious. Translated by J. Strachey. London: Vintage.

Fuentes, C. 2011. La gran novela latinoamericana. Madrid: Alfaguara.

García Canclini, N. 1995. Consumidores y ciudadanos. Conflictos multiculturales de la globalización. City of Mexico: Grijalbo. 
García Márquez, G. [1967] 2000. Cien años de soledad. Barcelona: Plaza y Janés.

García Márquez, G. 1982. El olor de la guayaba. Barcelona: Bruguera.

Gariano, C. 1978. “El humor numérico en Cien años de Soledad.” Hispania 61(3): 443-50.

Griffin, C. 1987. "The Humour in One Hundred Years of Solitude." In Gabriel García Márquez: New Readings, edited by B. McGuirk and R. Cardwell, 89-94. Cambridge: CUP.

Guadalupe Vargas, J. 2000. "Algunos mitos, estereotipos, realidades y retos de Latinoamérica". Cinta Moebio, 8: 232-53. http://www.moebio.uchile.cl/08/vargas02.htm [accessed 10 May 2015].

Hall, S. [1997] 2013. "The Spectacle of the 'Other'." In Representation: Cultural Representations and Signifying Practices, edited by S. Hall, J. Evans and S. Nixon, 215-87. London: The Open University.

Hart, S. M., and Ouyang W. 2005. "Introduction: Globalization of Magical Realism: New Readings of Aesthetics." In A Companion to Magical Realism, edited by S. M. Hart and W. Ouyang, 1-13. Tamesis: Woodbridge.

Higgins, J. 1990. “Gabriel García Márquez: Cien años de Soledad.” In Landmarks in Modern Latin American Fiction, edited by P. Swanson, 141-60. London: Routledge.

Hobbes, T. [1651] (1968). Leviathan, edited by C. B. Macpherson. Harmondsworth: Penguin.

Hutcheon, L. 1989. The Politics of Postmodernism. London: Routledge.

Jansen, A. 1992. "La progresión del humor de García Márquez en sus tres novelas mayores." In Actas del $X$ Congreso de la Asociación Internacional de Hispanistas 3, edited by A. Vilanova, 719-26. Barcelona: PUP.

Johnson, J. 1993. Satire in Colonial Spanish America: Turning the World Upside Down. Austin: University of Texas Press.

Koestler, A. 1967. The Act of Creation. New York: Dell.

Lacan, J. 1977. Écrits: A Selection, edited by J. A. Miller, translated by A. Sheridan. London: Tavistock.

Lopez-Mejía, A. 2013. "Race and Character in Cien años de soledad." Theory in Action 6: $29-49$

Manrique, N. 2000. "Modernity and Alternative Development in the Andes." In Through the Kaleidoscope: The Experience of Modernity in Latin America, edited by V. Schelling, 21947. London: Verso.

Marcos, J. 1989. "Mujer y violencia social en Cien años de soledad." In Violencia y literatura en Colombia, edited by J. Tittler, 91-95. Madrid: Editorial Orígenes. 
Martin, G. 1989. Journey's Through the Labyrinth: American Fiction in Twentieth Century Fiction. London: Verso.

Mignolo, W. 2000. Local Histories/Global Designs: Coloniality, Subaltern Knowledges and Border Thinking. Princeton: PUP.

Mignolo, W. 2007. La idea de América Latina. Translated by S. Jawerbaum and J. Barba. Barcelona: Editorial Gedisa.

Niebylski, D. 2004. Humoring Resistance: Laughter and the Excessive Body in Contemporary Latin American Women's Fiction. Albany: State University of New York Press.

Ortiz, R. 2000. "Popular Culture, Modernity and Nation." In Through the Kaleidoscope: The Experience of Modernity in Latin America, edited by V. Schelling, 127-47. London: Verso.

Paoli, R. 1984. "Carnavalesco y tiempo cíclico en Cien años de soledad." Revista Iberoamericana 50: 979-98.

Parrilla Sotomayor, E. 2002. "Ironía, humorismo y carnivalización en Cien años de soledad." Revista de Humanidades: Tecnológico de Monterrey 13: 31-46.

Penuel, A. 1994. Intertextuality in García Márquez. South Carolina: Spanish Literature Publications.

Pirandello, L. 1960. On Humour. Translated by A. Illiano and D. Testa. North Carolina: University of North Carolina Press.

Purdie, S. 1993. Comedy: The Mastery of Discourse. Hemel Hempstead: Harvester Wheatsheaf.

Rama, Á. 1984. La ciudad letrada. Hanover: Ediciones del Norte.

Roberts, G. 1976. "El sentido de lo cómico en Cien años de soledad." Cuadernos Hispanoamericanos 312: 708-22.

Rodríguez Monegal, E. 1985. "Traditions of Laughter." Review: Latin American Literature and Arts 35 (7): 3-6.

Rodríguez Vergara, I. 1991. El mundo satírico de Gabriel García Márquez. Madrid: Pliegos.

Said, E. [1978] 2003. Orientalism. London: Penguin.

Schelling, V. 2000. "An Introduction: Reflections on the Experience of Modernity in Latin America." In Through the Kaleidoscope: The Experience of Modernity in Latin America, edited by V. Schelling, 1-33. London: Verso.

Shaw, D. 1991. Nueva narrativa hispanoamericana. Madrid: Cátedra. 
Sims, R. L. 1990. "Archetypal Approaches." In Approaches to Teaching Gabriel García Márquez's One Hundred Years of Solitude, edited by M. E. de Valdés and M. J. Valdés, 97106. New York: The Modern Language Association of America.

Swanson, P. 1991. Como leer a Gabriel García Márquez. Madrid: Ediciones Júcar.

Swanson, P. 2010. "One Hundred Years of Solitude." In The Cambridge Companion to Gabriel García Márquez, edited by P. Swanson, 57-63. Cambridge: CUP.

Urbina, N. 1992. "Cien años de soledad: un texto lúdico con implicaciones muy serias." Revista Canadiense de Estudios Hispánicos 17: 137-52.

Vargas Llosa, M. 1971. García Márquez. Historia de un deicidio. Barcelona: Barral Editores.

Willams, R. [1958] 1983. Culture and Society, 1780-1950. New York: Colombia University Press. 